\title{
SZENIOR VERSENYÚSZÓK antropometriai értékeinek, életminôségének és táplálkozásának felmérése
}

Összefoglalás:

Régi új igazság, hogy a fizikai aktivitás egészséges, amit évezredek tapasztalatai és modern kutatások bizonyítanak. Ez azért aktuális hazánkban, mert a magyar lakosságra jellemző, hogy keveset mozog, és ez az egyik oka, hogy magas az elhízottak és túlsúlyosak aránya. A kutatás célja volt egyrészt vizsgáln a szenior versenyúszás, mint fizikai aktivitás

Abstract:

It is not a new statement that physical activity has a positive effect on health which is proved by experiences of centuries and modern researches. It is always relevant because Hungarian population has an inadequate level of physical activity what is one of the several reasons that the prevalence of obesity is high. The purpose of this study was to examine the hatását a testösszetételre és életminőségre, másrészt a táplálkozási szokások felmérése. A felmérésben részt vett szenior versenyúszók $(n=93)$ testzsír \% és vázizomtömeg értékei jobbak voltak a referenciaértékekhez képest. A felmért csoport életminősége is kedvező értékeket mutatott a magyar lakosság átlagértékeihez képest minden korcsoportban. $\mathrm{A}$ táplálkozásuk nagyobb arányban felelt meg az ajánlottnak, ám emellett is sok hiányosság volt kimutatható. Következtetésképpen a szakirodalmi adatok és a felmérés alapján elmondható, hogy a szenior versenyúszás pozitív hatással lehet a testösszetételre és életminőségre. Emellett az életmód másik fontos tényezője a helyes táplálkozás tudatositása fontos elem lehetne az egészségfejlesztés részeként.
Szerzők:

Tompa Orsolya

Semmelweis Egyetem

Eqészségtudományi

Kar, Dietetikai és

Táplálkozástudományi Tanszék,

Táplálkozástudományi MSc

hallgató

Dr. Biró Lajos

Semmelweis Egyetem

Egészségtudományi

Kar, Dietetikai és

Táplálkozástudományi Tanszék, adjunktus

Dr. Mák Erzsébet

Semmelweis Egyetem

Egészségtudományi

Kar, Dietetikai és

Táplálkozástudományi Tanszék, fóiskolai docens effect of Masters swimming on body composition and quality of life and to analyze nutrition. The data showed that masters swimmers $(\mathrm{n}=$ 93) have better body fat percentage and skeletal muscle mass values compared to the reference values. The quality of life scores were as well better compared to the average scores of the Hungarian population. The nutrition of the Masters swimmers was adequate in higher proportion than non-adequate compared to the nutritional recommendations but there was a considerable amount of inadequacies. In conclusion, according to the data of scientific literature and this study, masters swimming can have a positive effect on body composition and quality of life. Besides, to promote health it is recommended to improve nutrition which an important life style factor.

\section{Bevezetés:}

Régi-új, mondhatni örökérvényű igazság, hogy a fizikai aktivitás jó hatással van az egészségre, ennek ellenére a lakosság nem mozog eleget. Az ELEF 2016-os adatai szerint a WHO ajánlásának megfelelő heti testmozgást (150 perc/hét) végzők aránya egyik korcsoportban sem éri el a 30\%-ot, és minél öregebb a korcsoport, annál kevesebbet mozgunk (NEFI, 2017). Ez az egyik oka annak, hogy ennyire magas az elhízás és túlsúly aránya - közel kétharmad - Magyarországon (Kovács et al., 2016). A megfelelő fizikai aktivitási szint azért nagyon fontos, mert segít megelőzni bizonyos nem fertőző, krónikus betegségek előfordulását, ilyenek a kardiovaszkuláris megbetegedések, 2-es típusú diabétesz és bizonyos daganatos betegségek, így az össz-halálozást is csökkenti, tehát növeli az élettartamot (Schuit, 2006; Warburton et al, 2006; Reiner et al., 2013). Emellett protektív tényező Alzheimer kór és demencia kialakulása ellen (Laurin, et al., 2001; Apor - Rádi, 2010; Reiner et al, 2013). A kifejezetten idősek körében végzett vizsgálatok szerint a fizikai aktivitás (ami a szenior sportot is magába foglalja) segít megtartani a vázizomtömeget, lassítani a zsírtömeg növekedésének ütemét, csökkenti az esések, így a törések számát, lassítja a légzésfunkció és kognitív funkciók hanyatlását, és kedvező adaptációt hoz létre a szív- és érrendszerben (Sallinen et al., 2008; Apor - Rádi, 2010; Wroblewski et al., 2011). Emellett nagyon fontos hatása a szenior sportnak, hogy javítani tud az életminőségen, teljesebbé teszi az életet (Shephard et al., 1995; Chai et al., 2010). A szenior versenyúszás a fizikai aktivitás egy olyan formája, mely egy életen át hozzá tud járulni az egészségfejlesztéshez. Az elit versenysporttal ellentétben, mely manapság már egyre kevésbé nevezhető egészségesnek, a szenior sport valóban az egészségfejlesztés eszköze lehet egy életen át. A kutatás célja tudományos módszerekkel felmérni, hogy a szenior versenyúszás milyen hatással van a testösszetételre és életminőségre, emellett pedig a táplálkozás felmérése, ami az életmód másik fontos tényezője. Így cél megállapítani a felmért jellemzőkkel kapcsolatos tendenciákat, és összefüggést is keresni közöttük.

\section{Módszertan}

A kutatásnak alapvetően két része volt, az egyik része egy kérdőíves felmérés, a másik pedig egy eszközös testösszetétel-mérés. A kérdőív része volt az SF-36 egészséggel összefüggő életminőséget mérő kérdőív, melyet a RAND Health Corporation fejlesztett, magyarra fordított és validált, a magyar lakosság átlagértékei rendelkezésre állnak (Czimbalmos et al., 1999). A kérdőív másik része saját szerkesztésű volt, melyben általános, egészségre, sportra és táplálkozásra vonatkozó kérdések szerepeltek. A sportra vonatkozó kérdésekben voltak azok a kritériumok, melyek alapján a felmért csoportba lehetett kerülni. A bekerülési kritériumok: szenior klubban leigazolt, versenyszerüen úszik, heti minimum 2 edzése van és 25 év feletti.

A táplálkozási felmérés élelmiszercsoport fogyasztás gyakoriság alapú (FFQ) volt, melyet úgy alakítottunk ki, hogy össze lehessen hasonlítani a táplálkozási ajánlásokkal. A felmérés másik része testösszetétel-mérés volt InBody 170-es eszközzel, mely bioelektromos impedancia alapján mér, így meg tudja állapítani az izom és zsírtömeg arányát és mennyiségét. A kiértékelésben az InBody 170-es eszköz által megadott normál referenciatartományokat vettem figyelembe.

A mintavétel egyszerü, véletlen eljárással történt, a felmérésben való részvételre felhívás egyesületi e-mail-címeken és közösségi oldalon keresztül történt. A felmérésnek két helyszíne volt; a Semmelweis Egyetem Egészségtudományi Kar, Dietetikai és Táplálkozástudományi Tanszék antropometriai laborjában több alkalommal (2017. 07. 27-28., 2017. 08. 01-02. és 2017. 08. 21-23.), illetve egy Szentendrén megrendezésre került verseny kapcsán, a V-8-as uszoda orvosi szobájában (2017. 10. 14.).

A kapott adatokból leíró és összefüggés elemzéseket végeztünk (Excel 2013, SPSS 17).

\section{Eredmények}

\section{A mintacsoport jellemzői}

A kiértékelendő mintacsoportba végül 93 fő került, a kritériumoknak megfelelően kizárásra került 14 fő. A felmért csoportról elmondható, hogy 50,1 az átlagéletkor, átlagban 26 éve sportolnak és 4 edzésük van egy héten. A mintán belül korcsoportokat alakítottunk ki $(25-34,35-44,45-54,55-64,65+)$ az SF-36 korcsoportjai szerint, hogy összehasonlíthatóak legyenek az adatok. 


\section{Antropometriai eredmények}

A nők testzsír \% átlagai a különböző korcsoportokban azt mutatták, hogy a legfiatalabb 3 korcsoport (25-34, 35-44, 45-54) a normál tartományon (18-28\%) belül van $(21,8 \pm 5,7$, $21,7 \pm 6,4,21,2 \pm 5,4)$, az 55-64-es korcsoport a felső határt súrolja $(28,3 \pm 7,7)$. Egyedül a $65+$ korosztály lépi túl kevéssel a normál tartomány felső értékét $(31,4 \pm 8,8)$. Az összes korcsoport átlaga a normál tartományon belül helyezkedett el $(24,6 \pm 8)$.

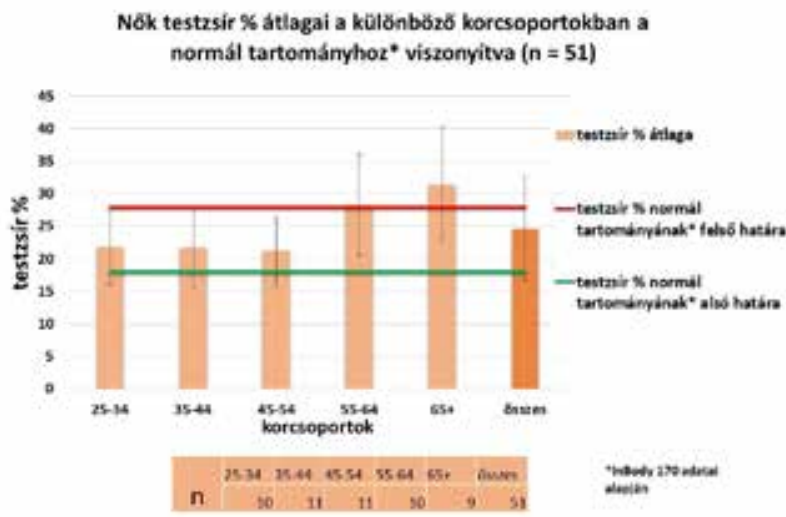

A férfiak testzsír \%-ának elemzésénél ugyanezen elv alapján alakítottuk ki a korcsoportokat. A nők eredményeivel ellentétben a férfiaknál minden egyes korcsoport átlagértéke a 10-20\%os normál tartományon belül voltak. A 25-34-es korcsoportnak $16,9 \pm 3,3$, a $35-44$-es korcsoportnak $14,5 \pm 3,7$, a $45-54$-es korcsoportnak $15,4 \pm 5,0$, az 55-64-es korcsoportnak 18,7 $\pm 5,6$, a legidösebb, $65+$-os korcsoportnak pedig 18,1 $\pm 5,6$. Az összes korosztály átlaga pedig $16,6 \pm 5,8$ lett.

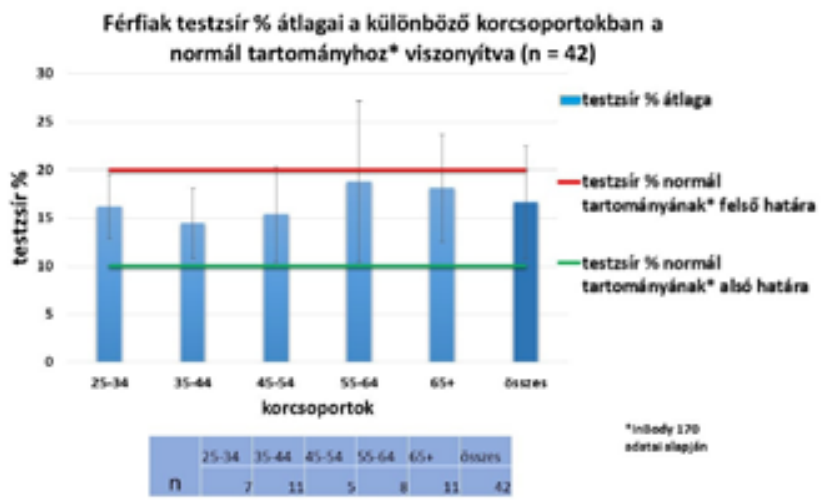

\section{Vázizomtömeg}

A vázizomtömeg eredményeinek leírása során probléma, hogy a normál tartomány az egyéni faktorok miatt mindenkinek eltéró az InBody 170-es kalkulációja alapján, ezért a normál tartományhoz viszonyított kategóriákat (alul, belül, felül) és a normál tartomány középértékétől való eltérést $(\mathrm{kg})$ vettük figyelembe.

A vázizomtömeg normál tartományához viszonyított kategóriánkénti megoszlása szerint mindössze 1 fő $(1 \%)$ volt, akinek a vázizomtömege a normál tartomány alatt volt. 55\%-nak, tehát a többségnek volt a vázizomtömege a normál tartományon felül, és $44 \%$-nak pedig a normál tartományon belül volt. Ez az eredmény hasonló volt a $65+$-os korosztályban is.

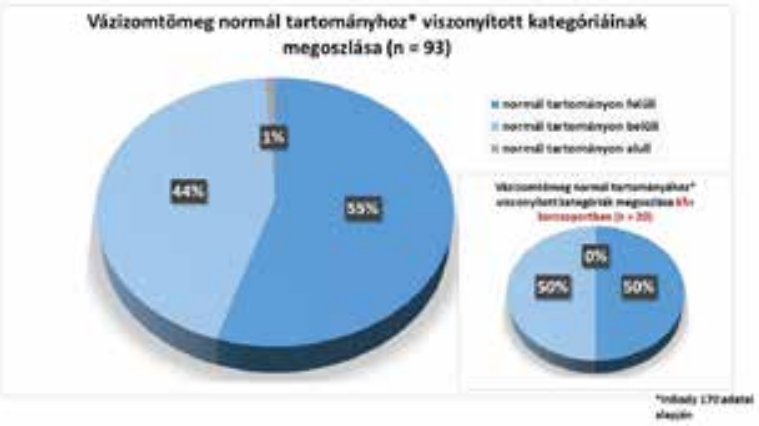

A következő diagramon a vázizomtömeg normál tartományának középértéktől való eltérése (kg-ban) látható ábrázolva. A piros vonal feletti pontok szimbolizálják az egyéneket, akiknek a normál tartomány középértéke felett volt a vázizomtömegük $(\mathrm{kg})$. A vonal alatti pontok azokat az egyéneket ábrázolják, akiknek a normál tartomány középértéke alatt volt a vázizomtömegük $(\mathrm{kg})$. Azt hozzá kell tenni, hogy a piros vonal alatti egyének vázizomtömege is még a normál tartományban volt, egy föt leszámítva, ahogy az előző elemzésből kiderült.

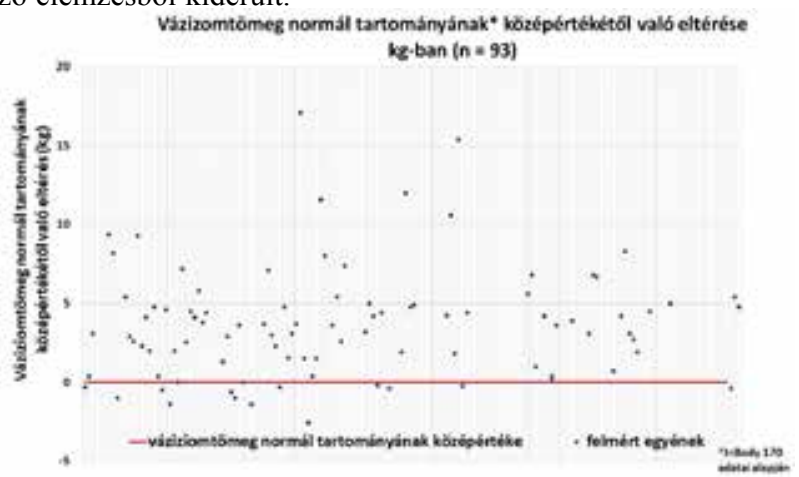

\section{Életminőség-eredmények}

Az egészséggel összefüggő életminőség-értékek az SF-36-os kérdőív segítségével lettek megállapítva. Az SF-36-ban 36 kérdés van összesen, ezeket 8 dimenzióba lehet csoportosítani; fizikai müködés, fizikai szerep, érzelmi szerep, vitalitás, testi fájdalom, szociális müködés, mentális egészség és általános egészség. A dimenziókat egy 0-100-ig terjedő skálán lehet kiértékelni. Az SF-36 magyar átlag értékeihez (Czimbalmos et al., 1999) hasonlítottuk a kutatásunk eredményeit.

$\mathrm{Az}$ eredmények ábrázolását pókháló diagrammal valósítottuk meg, a 8 életminőség-dimenzió szerinti bontásban. Jól látható a diagramon, hogy mind a 8 dimenzióban jobb átlagértékei voltak a felmért csoportunknak, ez a különbség különösen a fizikai szerep és az általános egészség dimenzióban mutatkozott meg.

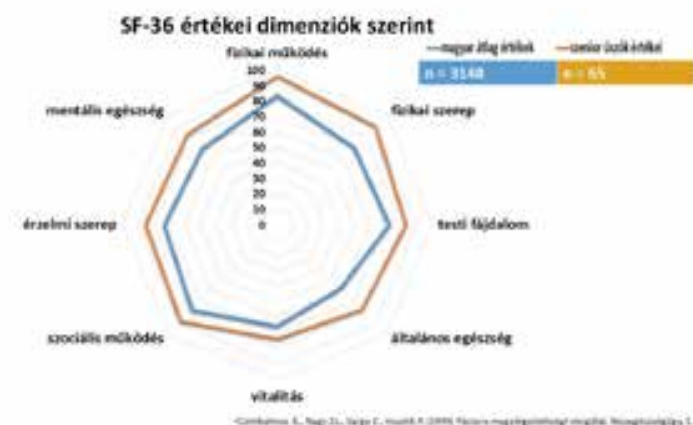

Táplálkozás kiértékelése

A táplálkozás felmérése élelmiszercsoport fogyasztás gyakoriság (FFQ) alapján történt. A gabona, teljes kiörlésű gabona, zöldség/gyümölcs, nyers zöldség/gyümölcs, tej/tejtermékek, hús/húskészítmények és alkohol a napi fogyasztás szerint lett értékelve, ettől eltérő a halfogyasztás, ahol a heti fogyasztás alapján értékeltünk (mert arra van ajánlás). Emellett a napi $3 x$ komplett fehérjefogyasztást vettük figyelembe az Okostányér ${ }^{\circledR}$ (MDOSZ, 2016) ajánlása alapján. Az összehasonlításhoz alapul vett ajánlás elsősorban az Okostányér®, ám mivel nem mindenre ad mérhető ajánlást, így más forrásokat is használtunk (Rodler, 2004; British Dietetic Association, 2016). A kiértékelésben az adagfogyasztás gyakoriságát vettük figyelembe az egyes élelmiszercsoportok alapján, és így megfelelt/nem felelt meg kategóriába osztottuk őket, amit százalékos bontásban írtunk le és ábrázoltunk. Az eredményeket elemezve megfigyelhetőek a tendenciák; az élelmiszercsoportok nagy részénél a megfelelt kategória volt nagyobb arányban. Ezzel ellentétben a tej/tejtermékek és a halfogyasztás tekintetében volt alacsonyabb a megfelelt aránya a nem megfelelthez képest. 


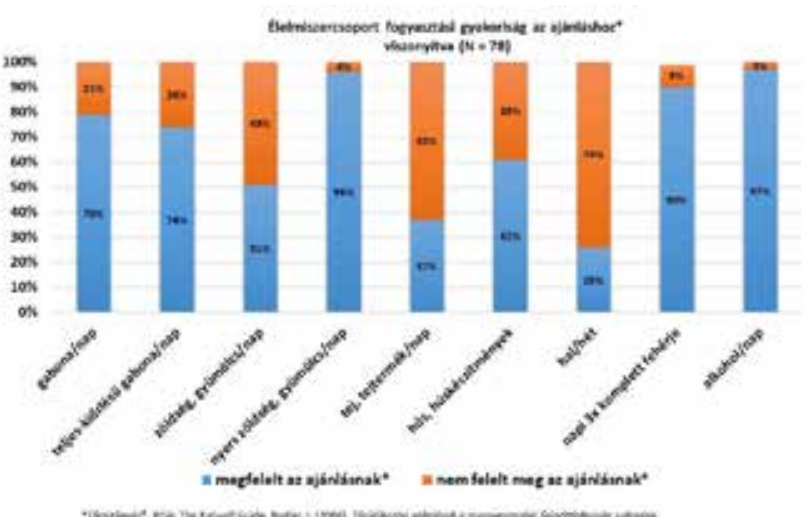

\section{Összefüggés-elemzés}

Összefüggés-elemzés az SF-36 életminőség-dimenzió értékei és az InBody 170-es antropometriai értékei között történt Khi négyzet próbával és Pearson-féle korrelációval.

Az összefüggés-elemzés megtörtént alcsoportokra bontva is: kor, nem, sportolt évek száma, heti edzésszám, beteg/nem beteg csoport. Szignifikáns összefüggést mindössze egy esetben sikerült kimutatni. A zsírtömeg $(\mathrm{kg})$ és a fizikai szerep SF-36 életminőségdimenzió között volt szignifikáns $(\mathrm{p}=0,029)$ negatív korreláció $(\mathrm{r}=0,247)$.

\section{Következtetések}

A felmért szenior versenyúszók antropometriai értékei kedvezőek voltak a referenciaértékekhez képest, ez összhangban van a szakirodalmi adatokkal is (Sallinen et al., 2008; Apor - Rádi, 2010; Apor, 2011; Wroblewski et al., 2011).

Ez azt mutatja, hogy a szenior versenyúszás pozitív hatással lehet a testösszetételre, különösen, ha azt nézzük, hogy milyen a magyar lakosság körében jelen lévő trend elhízás és túlsúly terén (Kovács et al., 2016). A felmért csoport életminőség-értékei jobbak voltak a magyar lakosság átlagértékeinél (Czimbalmos et al, 1999), ez különösen az idősebb korosztályokban látszódott.

Ezek az eredmények is a szenior versenysport pozitív hatását mutatják, és ezt a hatást már más hasonló, külföldi kutatások is igazolták (Shephard et al., 1995; Chai et al., 2010). A szenior versenyúszók táplálkozása nagyobb arányban felelt meg az ajánlottnak, mint nem. Ennek az eredménynek az értelmezésénél azt is figyelembe kell venni, hogy bár az FFQ alapú kérdőív egy jó eszköz ilyen jellegủ kutatásokhoz a táplálkozás felmérésére, de nem alkalmas teljesen pontos képet adni egy egyén táplálkozásáról.

A felmért eredmények ellenére is sok hiányosság volt kimutatható a felmért csoport táplálkozásában, így elmondható, hogy a táplálkozás javítása is fontos eleme lehetne az egészségfejlesztésnek. Az összefüggés-elemzéseknél egy kivételével nem jött ki szignifikáns összefüggés.

Ennek többféle magyarázata lehet, az egyik, hogy a szenior versenysport hatása komplexebb, mint az általunk vizsgált tényezők, a másik pedig, hogy az elemszám statisztikai értelemben alacsony volt, egyébként pedig magas, mert 1006 leigazolt szenior versenyúszóból 93-at sikerült elérni. Szignifikáns összefüggés egy negatív korreláció volt a fizikai szerep életminőség-dimenzió és a testzsírtömeg $(\mathrm{kg})$ között, ami azt jelenti, hogy akiknek alacsonyabb volt a zsírtömegük $(\mathrm{kg})$, azok jobbra értékelték a fizikai müködésüket. Ez logikus és megmagyarázható eredmény, mert azt mutatja, hogy akiknek alacsonyabb a zsírtömegük, azok könnyebben tudnak mozogni.

Összegzésképpen elmondható a szakirodalmi adatok és a felmérés alapján, hogy a szenior versenyúszás az egészség- és életminőség-fejlesztés fontos eszköze lehet egy egész életen át. Érdemes lenne népszerüsíteni a szenior sportot, és megteremteni a lehetőséget minél szélesebb körben; fiataloknak és időseknek is, mert a krónikus nem fertőző betegségek megelőzésében esszenciális szerepe van.

„Az Emberi Erőforrások Minisztériuma ÚNKP-17-2-I-SE-14 kódszámú Új Nemzeti Kiválóság Programjának támogatásával készült"

\section{Irodalomjegyzék}

Apor, P. (2011) Veterán (master) sportolók fizikuma, egészsége. Sportorvosi Szemle. 52. 2. 64-67.

Apor, P. - Rádi, A. (2010) Veterán sportolók: az idős, fizikailag aktív emberek egészsége és életkilátásaik. Orvosi hetilap. 151.3 DOI: 10.1556/OH.2010.28775

British Dietetic Association. (2016) New version of the Eat Well Plate. From: https://www.bda.uk.com/news/ view?id=112

Chai, W. - Nigg, C. R. - Pagano, I. S. - Motl, R. W. - Horwath, C. - Dishman, R. K. (2010) Associations of quality of life with physical activity, fruit and vegetable consumption, and physical inactivity in a free living, multiethnic population in Hawaii: a longitudinal study. International Journal of Behavioral Nutrition and Physical Activity. 7. 83. 1-6. DOI: 10.1186/1479-5868-7-83

Czimbalmos, Á. - Nagy, Zs. - Varga, Z. - Husztik, P. (1999): Páciens megelégedettségi vizsgálat SF-36 kérdőívvel, a magyarországi normálértékek meghatározása. Népegészségügy. 80. 1. 4-19.

Kovács, V.A., Erdei, G., Bakacs, M. (2016) A magyar lakosság tápláltsági állapota. From: http://www.ogyei.gov. hu/dynamic/3_kovacs_otap\%202014_ea_final.pdf

Laurin, D. - Verreault, R. - Lindsay, J. - MacPerson, K. Rockwood, K. (2001) Physical Activity and Risk of Cognitive Impairment and Dementia in Elderly Persons. Archives of Neurology. 58.3.498-504. DOI: 10.1001/archneur.58.3.498

NEFI (2017) Egészségjelentés 2016. From: http:// www.egeszseg.hu/szakmai_oldalak/assets/cikkek/17-05/ egeszsegjelentes-2016.pdf

MDOSZ (2016) Okostányér ${ }^{\circledast}$ - Új magyar táplálkozási ajánlás. From: http://mdosz.hu/uj-taplalkozasi-ajanlasokokos-tanyer/

Reiner, M. - Niermann, C. - Jekauc, D. - Woll, A. (2013) Long-term health benefits of physical activity - a systematic review of longitudinal studies. BMC Public Health. 13.813. 1-9. DOI: 10.1186/1471-2458-13-813

Rodler I., (2004) Táplálkozási ajánlás a magyarországi felnőtt lakosság számára. Országos Egészségfejlesztési Intézet, Budapest

Sallinen, J. - Ojanen, T. - Karavirta, L. - Ahtiainen, J. P. - Häkkinen, K. (2008) Muscle mass and strength, body composition and dietary intake in master strength athletes vs untrained men of different ages. The Journal of Sports medicine and physical fitness. 48.2.190-196

Schuit, A. J. (2006) Physical activity, body composition and healthy ageing. Science \& Sports. 21.4.209-213 DOI: 10.1016/j.scispo.2006.06.004

Shephard, R. J. - Kavanagh, T. - Mertens, D. J. - Qureshi, S. - Clark, M. (1995) Personal health benefits of Masters athletics competition. British Journal of Sport Medicine. 29.1.35-40.

Warburton, D. E. R. - Nicol, C. W. - Bredin, S. S. D. (2006) Health benefits of physical activity: the evidence. Canadian Medical Association Journal.174. 6. 801-809. DOI: 10.1503/cmaj.051351

Wroblewski, A. P. - Amati, F. - Smiley, M. A. - Goodpaster, B. - Wright, V. (2011) Chronic exercise preserves lean muscle mass in masters athletes. The Physichian and Sport Medicine. 39.3. 172-178. DOI: 10.3810/psm.2011.09.1933 